\title{
Ole Brumm-syndromet
}

Sommeren 1983 var jeg hospitant ved barnesykehuset i Praha. Avstanden mellom Tsjekkoslovakia i Sovjetunionens jerngrep og et nyrikt Norge drøye ti år etter de første oljefunnene i Nordsjøen, midt $i$ en politisk høyrebølge og med Kåre Willoch som statsminister, var stor i mer enn en forstand. Det var mye å observere både i og utenfor sykehuset for en medisinstudent. Noe av det første jeg la merke til, var køene og det svært begrensede utvalget av varer i forretningene. Folk sto tålmodig i kø overalt, for alt. Varene de ventet på var ikke dårlige, men ofte ganske kjedelige, syntes jeg. Men alle fikk - og tilsynelatende nok til at de klarte seg. Det var lite ekstravaganse, men heller ingen åpenbar materiell fattigdom - og det var likt for alle. Selvsagt med unntak av en liten politisk elite som hadde mer enn nok. På sykehuset var det på samme vis. Det var mangel på medikamenter, utstyret var gammeldags og enkelt. Men det faglige nivået hos helsepersonellet var det ingenting å utsette på - til tross for begrenset tilgang på bl.a. vestlig medisinsk faglitteratur og nye forskningsresultater. Og tilbudet var likt for alle. Medbestemmelse for pasienter sto ikke på dagsordenen. Dermed ble helsevesenet også billig og effektivt. Jeg husker spesielt de små barna som skulle tonsillektomeres. Foreldrene avleverte dem ved inngangen til sykehuset (foreldre på et barnesykehus skapte bare ekstra bry). Når det var klart for operasjon, ble barna satt på en stol. De lente hodet litt fremover, en sykepleier holdt dem fast og så kom legen og røsket ut tonsillene. Det hele var over med et skrik, bokstavelig talt.

Slik er det ikke lenger i de tidligere østblokklandene. Sentralstyrt, statlig kontrollert økomoni og politikk er erstattet med mer markedsbaserte systemer. Det har selvsagt fått konsekvenser både for helsetjenesten og samfunnet for øvrig. De fleste køene er borte, vareutvalget er større - men alle kan ikke velge. Det er blitt flere valgmuligheter, men også flere ulikheter, både materielt og sosialt. Alt har sin pris.

President Barack Obama gikk til valg på å få gjennomført en helsereform i USA allerede i 2009. Det gikk ikke. Nå strever presidenten i politisk motbakke, og det er uvisst om og hva slags helsereform amerikanerne vil få. Landet bruker over $16 \%$ av bruttonasjonalproduktet på helsetjenester, 7290 dollar per innbygger, nesten dobbelt så mye som Norge. Likevel er over 45 millioner amerikanere uten helseforsikring, og enda flere er «underforsikret». Dessuten er den forventede levealderen lavere og barnedødeligheten høyere enn i land USA liker å bli sammenliknet med. Forekomsten av kroniske sykdommer og overvekt har eksplodert (nesten $35 \%$ av befolkningen har en BMI $>35 \mathrm{~kg} / \mathrm{m}^{2}$ ). Kort sagt, verdens mest kostbare helsevesen gir åpenbart ikke verdens friskeste befolkning. Når man legger til at amerikanere flest er langt fra fornøyd med helsetjenesten, skulle man tro at det ville være bred oppslutning om en reform - både for å få kontroll på økonomien og for å få en bedre helsetjeneste for alle. Men amerikanerne er lunkne. Når de ser til f.eks. Canada og Skandinavia, ser de ikke bare lavere kostnader og like rettigheter til helsetjenester for alle, de ser også noe av det samme som jeg så i Praha 1983: Køer og lange ventetider for helt nødvendige helsetjenester, få reelle alternativer å velge mellom. De ser rasjonering (også kalt prioritering) av tjenester. De ser sentralstyring og byråkrati. Det liker de dårlig. Individuell valgfrihet som prinsipp er viktig i USA - også når den ikke er reell (som den jo ikke er for de fattigste). Men bare tanken på å sette redusert individuell valgfrihet $i$ system, det at staten skal bestemme hva slags helsetjenester de skal få, skremmer amerikanerne. Skremmebilder av hva «sosialistisk helsetjeneste» innebærer, f.eks. at syke eldre nærmest settes bort for å dø, florerer i deler av amerikansk offentlighet. Befolkningen i USA vet godt at frihet koster, og de fleste mener nok at helsesektoren er altfor kostbar, men foreløpig ser det ut til at de er villige til å betale prisen - gitt alternativene.

Mange later til å tro at vi kan få en «perfekt» helsetjeneste gjennom de rette «grep»: organisatoriske, juridiske og økonomiske. Men den beste helsetjenesten for en befolkning eller et individ er avhengig av verdier og preferanser. Køer og ventetid kan bli borte, kvaliteten og kostnadskontrollen kan bli bedre. Det kan bli større likhet og større valgfrihet. Alt går an å få til - men ikke samtidig. Det er ønsketenkning. Vi har nettopp sett det i sykelønnsdebatten. Det går an å ønske seg et produktivt og effektivt arbeidsliv, et inkluderende arbeidsliv og et lavt sykefravær. Men man kan ikke få alt på en gang. Et reelt inkluderende arbeidsliv blir f.eks. neppe like effektivt, og man må sannsynligvis akseptere høyere sykefravær.

På samme måte må det velges i helsetjenesten. Og vi snakker ikke om enkle valg som om man skal tillate den eller den nye kreftbehandlingen. Vi snakker om å besvare spørsmål og gjøre valg som vil drive helsetjenesten $i$ vidt forskjellige retninger. Ønsker vi et billig og effektivt helsevesen, offentlig finansiert og likt for alle? Det går an, men prisen er køer og begrenset utvalg. Ønsker vi å fjerne køene og ventetiden? Skal vi ha reell valgfrihet med henblikk på behandler og behandling? Ønsker vi best mulig kvalitet på tjenestene? Det går også an, men det blir dyrt. Sannsynligvis så dyrt at det offentlige ikke kan ta hele regningen. Da blir tilbudet avhengig av den enkeltes betalingsevne.

I Norge har vi lenge stukket hodet i sanden og håpet at oljepengene kunne redde oss. Vi har sagt «ja takk, begge deler»! Vi har f.eks. innført et system innen spesialisthelsetjenesten som belønner «produktivitet» og kostnadskontroll. Samtidig har pasientene på papiret - individuelle rettigheter til fritt sykehusvalg og til å få diagnostikk og behandling uten unødig ventetid. Det lar seg ikke kombinere.

\section{Charlotte Haug}

redaktør 